\title{
Ontogeny of sexual behavior in stallions
}

\author{
Sue M. McDonnell \\ Havemeyer Equine Behavior Lab, University of Pennsylvania, School of Veterinary Medicine, New Bolton Center
}

\begin{abstract}
Summary
All elements of male and female sexual behavior occur both in male and female foals from the first week of age. Older juveniles engage in fully organized precopulatory and copulatory sequences with appropriate target females as early as 6 months of age. Although this early sexual behavior is typically interpreted as "play“ young males may sire foals before the age of one year. Under free-running conditions stallions obtain a harem either as a young male associating with a young female, or after some years as a member of all-male groups known as the bachelor bands. Bachelor stallions engage in on-going inter-male sexual interaction and occasional heterosexual encounters with young females. In rare instances, colts as young as two years old have been observed to establish and maintain a long-lasting harem band. Domestic stallions typically retain the ability to establish and maintain a harem, even if after many years of domestic stabling and managed handbreeding.
\end{abstract}

Keywords: $\quad$ Sexual behaviour, stallion

\section{Entwicklung des Sexualverhaltens beim Hengst}

Alle Elemente des männlichen und weiblichen Sexualverhaltens treten beim Hengst- und Stutfohlen von der ersten Lebenswoche an auf. Frühestens ab dem 6. Lebensmonat sind bei heranwachsenden männlichen Fohlen die kompletten Abläufe des Vorspiels und der Kopulation mit zu ihnen passenden Stuten zu beobachten. Obwohl dieses Sexualverhalten normalerweise als "Spiel“ interpretiert wird, ist es möglich, daß Junghengste vor Erreichen ihres ersten Lebensjahres eine Stute befruchten. In der freien Wildbahn beschaffen sich Hengste einen Harem, entweder indem sie sich mit einer Jungstute zusammentun oder nach ein paar Jahren Mitglied in einer Junggesellengruppe - bachelor band werden. Junggesellen-Hengste gehen dauerhafte homosexuelle Beziehungen ein, gelegentlich kommen heterosexuelle Begegnungen mit Jungstuten vor. Nur sehr selten kann beobachtet werden, daß zweijährige Hengste einen beständigen Harem etablieren und aufrechterhalten. Domestizierte Hengste behalten normalerweise die Fähigkeit zum Aufbau und Verteidigung eines Harems bei, auch nach langen Jahren der Stallhaltung und des Zuchtmanagements durch den Menschen.

Schlüsselwörter: Sexualverhalten, Hengst

\section{Introduction}

Limited work has addressed description of sexual behavior of stallions as it develops from birth through maturity. This review summarizes what is currently known about stallion sexual behavior development, both in equids living under free-running or under pasture breeding conditions as well as domestic stallions kept under various management systems. This review is based on several key studies of domestic, wild, and feral equid populations listed in the references, on the author's published and unpublished observations of pasture-breeding domestic horses, and particularly on longitudinal study of a semi-feral herd of Shetland type ponies kept at our facility specifically for the long-term study of their sociosexual behavior and physiology of horses (McDonnell, 1994-present).

\section{Foal sexual behavior}

Foals, both in natural and domestic herd social environments exhibit sexual behavior from as early as the first week. This sexual behavior takes a form commonly interpreted as „play behavior“. Sexual behavior within the first week or two occurs mostly in interactions with the dam, and then later occurs in interactions among foals and among foals and juveniles, as well as with maturing and adult females other than the dam. Specific precopulatory and copulatory responses commonly exhibited by foals include olfactory investigation of urine and feces, flehmen response, and urine and fecal marking of these substances; olfactory investigation, nuzzling and licking of estrous females and their voided urine and feces, with flehmen response; mounting with and without erection, and pelvic thrusting. Vaginal insertion, fully organized thrusting, or signs of ejaculation are rare in neonatal foals. Male foals in play among juveniles also show elements of female sexual behavior, either as the target "female" in interactions with male foals or as the target of female foals playing the „male" role.

This early sexual behavior appears to develop from initially disjointed and awkward responses and sequences to eventually well-organized mature style responses and sequences. This phenomenon suggests that this early sexual behavior may serve a „practice“ function. The frequency and duration of sexual behavior increases with estrus of the dam or other females within the band, suggesting that the foal recognizes or is appropriately stimulated by estrus. The 
juvenile sexual behavior appears to be fully tolerated by the adults, both the harem mares and the harem stallion. Typically, the adult females do not actively solicit or respond sexually to a foal as they would to an adult stallion, simply tolerate the „play“. To the extent allowed, similar behavior is seen in foals that are managed under various domestic systems. Interestingly, this early sexual behavior sometimes raises concerns that it represents abnormal precocious or „deviant" sexual behavior.

\section{Juvenile and peri-pubertal sexual behavior}

Sexual behavior continues in colts as they develop. While adult females may still be the stimulus and target, under natural social herd conditions most of the sexual type responses and sequences occur within juvenile „play groups“. Beginning as early as a few months of age, juvenile males participate in group heterosexual breeding encounters with young (approximately one year old) estrous females. In these juvenile „parties", colts serially breed one or more young females. It seems that the older colts become more organized in their precopulatory and copulatory sequences. Insertion, organized thrusting, and ejaculation may or may not occur. In our semi-feral pony band, juvenile breedings are fertile for colts as young as 8 months breeding fillies as young as 9 months. Sexual interactions among juvenile pairs or in these „parties“ often occur within or at the edge of the harem group, and are almost always tolerated by harem stallions.

Evidence indicates that stallions under domestic management can be sexually competent and fertile before one year of age, when given the opportunity to interact with females. Skinner and Bowen (1968) reported that Welsh pony stallions reached puberty (as defined by semen collected by artificial vagina) between 11.5 and 14.5 months of age. Naden et al. (1990) evaluated semen, endocrinology, and sexual behavior of fifteen domestic Quarter Horse colts every two months from 8 to 24 months of age. They reported that these animals reached puberty (defined as the ability to ejaculate 50 million sperm with at least $10 \%$ total motility under semen collection conditions) by 13 to 24 months of age. In these studies sexual behavior competence occurred at approximately one year of age for the Welsh ponies and between 1 and 2 years of age for the Quarter Horse type colts. In unpublished work from our lab, four domestic pony foals (born in May through July) that were given twice weekly access to an estrous mare from birth through 3 years of age experienced their first ejaculation at 7 to 9 months of age. Interestingly, all four first ejaculated on the same first warm spring day of that year, February 14th (St. Valentines Day).

\section{Adult sexual behavior}

Under natural social conditions, young stallions typically leave the natal band to immediately or eventually join ba- chelor bands sometime between approximately one and four years of age. Bachelor males may breed with young females in temporary associations as they wander in transition from their natal band or on the edge of harem bands. The form of bachelor heterosexual precopulatory and copulatory behavior is similar to that of a harem stallion.

Bachelor males also engage in considerable (many encounters per day per stallion) inter-male sexual behavior interspersed with ongoing sparring aggressive interactions and peaceful close interactions similar to that of harem adult mares and females McDonnell and Haviland, 1995). In these inter-male interactions among bachelors in our semiferal pony herd, all bachelor males play both male and female roles (Plebani and McDonnell, 1997).

Under natural social conditions, stallions obtain a harem in one of two typical ways. Young males in transition from the natal band sometimes form an association with one or more young females in transition from the natal band, and then go on to become a stable harem. For these young colts and fillies, the association often begins as a loose and playful type affiliation. Harem type herding and vigilance develops gradually over the first year of the association. These young colts may simultaneously affiliate with other young males from former play groups. Another way in which stallions become a harem stallion involves obtaining one or more mares after some time as a bachelor. Again, the mares are often young females leaving their natal band. At the time a mature stallion obtains a harem, he immediately exhibits a variety of herding and harem protective behaviors, as well as the precopulatory and copulatory sequences. Inter-male behavior of a new harem stallion immediately shifts from the sparring and cooperative behavior typical of bachelors to extremely aggressive behavior toward other harem stallions and toward adult bachelor stallions.

Under domestic conditions, most stallions given free access to mares exhibit normal harem formation and maintenance behaviors, even after many years of managed in-hand breeding in which sexual behavior is limited to immediate precopulatory and copulatory sequences.

\section{Literature}

Berger $J(1977)$ : Organizational systems and dominance in feral horses in the Grand Canyon. Behavior, Ecology, and Sociobiology 2, $91-119$.

Berger J (1986): Wild Horses of the Great Basin. Chicago: University of Chicago Press.

Feist $J$ and Mcullough $D$ (1975): Reproduction in feral horses. Journal of Reproduction and fertility Supplement 23, 13-18.

Keiper RR (1985): The Assateague Island Ponies. Centreville, Maryland, USA, Tidewater Publishers.

Hoffmann R (1985): On the development of social behaviour in immature males of a feral horse population (Equus Przewalski f. caballus). Z Säugetierkg 50, 302-314.

McDonnell SM and Murray SC (1995): Bachelor and harem stallion behavior and endocrinology. Equine Reproduction Vl, Biology of Reproduction Monograph Series 1, 135-148.

McDonnell SM and Haviland JCS (1995): Agonistic ethogram of the equid bachelor band. Applied Animal Behavior Science 43, 147-188. 
Miller $R$ (1981): Male aggression, dominance and breeding behavior in Red Desert feral horses. Z. Tierpsychol 57, 340-351.

Naden J, Amann RP, Squires EL. (1990): Testicular growth, hormone concentrations, seminal characteristics and sexual behavior in stallions. J Reprod Fert 88, 167-176.

Plebani JG and McDonnell SM (1997): Patterns of inter-male sexual behavior in stallions. 31st International Congress of the International Society for Applied Ethology, Prague, Czech Republic, August 13-16.

Schoen AMS, Banks EM, Curtis SE (1976): Behavior of young Shetland and Welsh Ponies (Equus caballus). Biology of Behaviour 1 , 192-216.

Tyler S (1972): Behaviour and social organization of the New Forest ponies. Animal Behaviour Monographs 5, 85-196.
Wells SM and von Goldschmidt-Rothschild B (1979): Social behaviour and relationships in a herd of Camargue horses. Z Tierpsychol 49, 363-380.

Sue M. MCDonnellL, PhD

Havemeyer Equine Behavior Lab

University of Pennsylvania School of Veterinary Medicine

New Bolton Center

382 West Street Road, Kennett Square, PA 19348

Phone: $610-444-5800$

Fax: 610-444-8124

Email: suemcd@vet.upenn.edu

\section{3rd Maastricht International Congress on Equine Medicine 27th of November 1999}

\section{Elbow and shoulder joint}

Radiology and scintigraphy of the elbow and shoulder joint.

Lameness associated with the elbow and shoulder regions: how useful is ultra-sonography?

Soft tissue injuries in the elbow and shoulder region of the horse.

The management of fractures of the upper forelimb in horses.

Arthroscopy of elbow and shoulder joint.

Surgical treatment of bone cysts - transplantation of bone and cartilage grafts by the OATS-method.

Stadtbäumer, GER

Dyson, UK

Walmsley, UK

Greet, UK

Mcllwraith, USA

Rapp, GER

\section{Soft tissue injuries - reconstructive surgery}

Skin lesions in horses - a cosmetic problem?

Wound closure in human reconstructive surgery - what is possible in equine medicine?

Stadler, GER

Topics

New methods in the treatment of infections of the CNS: filtration of CSF.

Developments in nutriceuticals and resistence - Prevention planning with food additives.

Küppers, GER

Colic

Cecocecal and cecocolic intussusceptions

The pros and cons of using staples in intestinal surgery.

Different techniques of jejunal anastomosis - a comparison of conventional suturing versus stapling -

clinical and morphological findings.

Diagnostic and surgical laparoscopy in the chronic colic case.

Ultrasonic diagnosis of abdominal masses.

Some uncommon diseases of stomach and duodenum

Management of rectal tears.

Grabner, GER

Andreasen, CAN

Freeman, USA

Greet, UK

Köhler, GER

Walmsley, UK

Mettenleiter, GER

Huskamp, GER

Freeman, USA

\section{Pharmaceutical news}

New trends in sedation, analgesia and general anesthesia in the horse.

Schatzmann, $\mathrm{CH}$

The use of Hyonate intravenously in traumatic arthritis of the horse.

A comparison of Bapten with other medical treatments of tendonitis.

Mcllwraith, USA

Dyson, UK

A practical view on intravenously pain treatment.

The role of Quadrisol $50 \mathrm{mg} / \mathrm{ml}$ for I.V. injection for horses

van Oijen, NL

The European equine veterinarian in the year 2000

Thoughts about a standardized prepurchase examination in Europe.

Rasch, GER

FEEVA (Federation of European Equine Veterinary Association): your professional equine

veterinary platform in Europe.

Back, NL, Fenner, GER, Jones, UK

Tagungsgebühren:

Information und Anmeldung:
Eur 155 (bei Überweisung bis zum 31. 10.1999), Eur 180 (nach dem 1.11.1999)

Pferdeklinik Kerken, Slümerstraße 5-6, D 47669 Wachtendonk

Tel: 02836 91410, Fax: 02836 852898, e-mail: micem99@hotmail.com,

website: hitp://come.to/micem99 